\title{
Optimal screening of heart failure patients: tissue Doppler imaging or plasma NTpro BNP measurement?
}

\author{
Leo H. B. Baur
}

Received: 17 December 2007/Accepted: 26 December 2007/Published online: 31 January 2008

(C) The Author(s) 2008

Early detection and treatment of left ventricular dysfunction is of major importance. Ideally, therapy will be performed before irreversible cardiac damage has occurred. To do this, a sensitive evaluation of cardiac function and cardiac mechanics is required. However, cardiac function is difficult to define and the assessment of function in a clinical context often uses a surrogate for function. One can divide cardiac function in intrinsic myocyte function or contractility and ventricular pump function [1]. Force development results in the generation of sufficient pressure to open the cardiac valves. On the other hand results deformation of the ventricles in the ejection of blood. The interaction between force development and deformation are determined by ventricular wall properties such as tissue composition, fibre structure and global geometry on one hand and the interaction between the heart and the loading conditions on the other hand. The most reliable parameter to measure intrinsic myocardial contractility is by calculation of the end-systolic pressure-volume relationship (E-max) [2]. This is an invasive technique and not always applicable in clinical practice. Therefore in clinical practice, surrogate measurements of force development and volume ejection are used with non-

L. H. B. Baur $(\bowtie)$

Department of Cardiology, Atrium Medical Centre

Parkstad, Henri Dunantstreet 5, 6401CX Heerlen,

The Netherlands

e-mail: 1br01@atriummc.nl invasive techniques, like echocardiography, magnetic resonance imaging or computed tomography. The evaluation of ejection fraction with these techniques, however has severe shortcomings because the assessment of intrinsic cardiac function using ejection fraction depends on geometric assumptions. Volume based indices are load dependent and these parameters only assess global function. To overcome these problems, new echocardiographic techniques, like tissue Doppler imaging have been developed, which measure myocardial motion and deformation.

Tissue Doppler imaging uses the shifts of ultrasound waves to calculate myocardial velocity. It can be done with the pulsed Doppler technique and the color-coded tissue Doppler technique. Measurement of the ratio of transmitral peak inflow velocity of early rapid diastolic filling (E), and measurement of Ea, obtained by pulsed-TDE sample volume placed in the lateral annulus imaged from the four chamber view can be used as an indicator of left ventricular filling pressures [3].

Brain natriuretic peptide is a natriuretic hormone, that is present in the heart, particularly in the ventricles. Brain natriuretic peptide has diuretic, natriuretic and hypotensive effects. It inhibits the rennin-angiotensin system, endothelin secretion and sympathetic activity [4]. The release of BNP is increased in heart failure, as ventricular cells secrete BNP in response to high ventricular filling pressures [5]. In normal subjects, the plasma concentrations of BNP and NT-proBNP are similar. However, in 
patients with left ventricular dysfunction, plasma NTproBNP rises more than BNP [6]. It can be used to diagnose but more to rule out heart failure. BNP can be used as a bedside test to rule out heart failure at the first aid department in patients with dyspnea [7]. Although the sensitivity, specificity and predictive value are high in patients with sinusrythm, BNP loses its sensitivity and specificity in patients with atrial fibrillation [8]. False positive NT pro-BNP results can be diminished by adding the age of and clinical characteristics of the individual for stratification of patients with dyspnea $[9,10]$.

The current study of Mornos et al. [11] showed a close correlation of NT-proBNP with a combination of conventional Doppler echocardiography of the $\mathrm{E}$ velocity of transmitral flow and two TDI parameters: $\mathrm{Ea}$ and Sa. The last parameters explore both diastolic and systolic left ventricular performance.

The study shows, that after initial screening of heart failure patients with BNP or NT-proBNP additional echocardiographic imaging with TDI can give the information about ventricular geometry, morphology and the presence of systolic or diastolic function. The study also shows, that tissue Doppler imaging has to become a standard tool for the evaluation of heart failure patients. We have to keep in mind however, that measurement of plasma BNP or NT-proBNP can help in discrimination of dyspnea of cardiac or non-cardiac causes, but gives no information about the etiology of cardiac dyspnea. Cardiac imaging with echo, Doppler echo, tissue Doppler echo, Stress Echo, Magnetic Resonance Imaging, Stress MRI, Nuclear (Stress Imaging) and Conventional Coronary angiography or CT coronary angiography is still needed to explore the underlying cardiac pathology.

Open Access This article is distributed under the terms of the Creative Commons Attribution Noncommercial License which permits any noncommercial use, distribution, and reproduction in any medium, provided the original author(s) and source are credited.

\section{References}

1. Bijnens B, Claus P, Parsai C, Weidemann F, Marciniak A, Anderson L, Sutherland GR. Assessing Cardiac Function in Dilated and Failing Hearts. In: Sutherland GR et al., Doppler myocardial imaging chapter 11:251-277

2. Kass DA, Yamazaki T, Burkhoff D, Maughan WL, Sagawa K (1986) Determination of left ventricular endsystolic pressurevolume relationships by the conductance (volume) catheter technique. Circulation 73:586-595

3. Ommen SR, Nishimura RA, Appleton CP, Miller FA, Oh JK, Redfield MM, Tadjik AJ (2000) Clinical utility of Doppler echocardiography and tissue Doppler imaging in estimation of left ventricular filling pressures: a comparative simultaneous Doppler-catheterization study. Circulation 102: 1788-1794

4. Brunner- La Rocca HP, Kaye DM, Woods RL, Hastings J, Esler MD (2001) Effects of intravenous brain natriuretic peptide on regional sympathetic activity in patients with chronic heart failure as compared with healthy control subjects. J Am Coll Cardiol 37:1221-1227

5. Kinnunen P, Vuolteeaho O, Ruskaoho H (1993) Mechanisms of atrial and brain natriuretic peptide release from rat ventricular myocardium: Effect of stretching. Endocrinology 132:1961-1970

6. Hunt PJ, Richards AM, Nicholls MG, Yandle TG, Doughty RN, Espiner EA (1997) Immunoreactive amino-terminal pro-brain natriuretic peptide (NT-ProBNP): a new marker of cardiac impairement. Clin Endocrinol 47:287-296

7. Maisel AS, Krishnaswamy P, Nowak RM, McCord J, Hollander JE, Duc P, Omland T, Storrow AB, Abraham WT, Wu AH, Clopton P, Steg PG, Westheim A, Knudsen CW, Perez A, Kazanegra R, Herrmann HC, McCullough PA (2002) Breathing not properly multinational study investigatorset. Rapid measurement of B-type natriuretic peptide in the emergency diagnosis of heart failure. $\mathrm{N}$ Engl $\mathrm{J}$ Med 347:161-167

8. Knudsen CW, Omland T, Clopton P, Westheim A, Wu AH, Duc P, McCord J, Nowak RM, Hollander JE, Storrow AB, Abraham WT, McCullough PA, Maisel A (2005) Impact of atrial fibrillation on the diagnostic performance of B-type natriuretic peptide in dyspneic patients: an analysis from the Breathing Not Properly multinational study. J Am Coll Cardiol 350:838-844

9. Januzzi JR, van Kimmenade RRJ, Lainchbury JG, BayesGenis A, Pinto YM, Richards AM (2006) NT-proBNP testing for the diagnosis and shortterm prognosis in acute congestive heart failure: an international pooled analysis of 1256 patients. The International Collaborative of NTproBNP (ICON) Study. Eur Heart J 27:330-337

10. Van Kimmenade RJ, Pinto YM, Bayes-Genis A, Lainchbury JG, Richards M, Januzzi JL (2006) Usefulness of intermediate amino-terminal pro-brain natriurteric peptide concentrations for diagnosis and prognosis of acute heart failure. Am J Cardiol 98:386-390

11. Mornos C, Ionac A, Cozma D, Rusinaru D, Maximov D, Petrescu L, Lupu A, Dragulescu S. The relationship between tissue Doppler imaging and seric NTproBNP levels in sinus rythm patients: a prospective study. Int $\mathbf{J}$ Card Imaging. doi:10.1007/s10554-007-9279-8 